\title{
Teaching English to Young Children
}

\author{
- Ganga Ram Gautam
}

\begin{abstract}
In the context of Nepal, teachers often prefer to teach at the higher level. In my professional career, I have met very few people who really enjoy teaching at the preprimary or primary level. According to them, teaching young children is very challenging and managing learning at that level is very difficult. My experience is different. I have taught the young children for some time in the past and I enjoyed it very much. Children bring a lot of energy and enthusiasm and if a teacher can make use of that energy in creating learning atmosphere in class, both the children and teacher enjoy being in the pre-primary and primary classes. This article presents some observations and activities to encourage teachers to teach English at the pre/primary level and make English teaching a fun experience.
\end{abstract}

Key words: Young children, language games, language activities, energy and enthusiasm, mothering.

\section{Nature and characteristics of young children}

There is often a myth that young children who come to school at primary level do not know much and they are like blank sheet of paper. It may be true that they are innocent but they know a lot and they can do several things at very young age. According to (Scott \& Y treberg, 1990), five to seven year old children can do the following things;
a) They can talk about what they are doing.
b) They can tell you about what they have done or heard.
c) They can plan activities.
d) They can argue for something and tell you why they think what they think.
e) They can use logical reasoning.

f) They can use their vivid imaginations.

g) They can use a wide range of intonation patterns in their mother tongue.

h) They can understand direct human interaction.

Children are amazing and they have a so much to offer in class and it is the teacher who needs to learn how to manage this in class.

\section{Teaching young children}

"Teaching young children is a salutary (good though seem unpleasant) experience; one cannot 'get away' with it being unprepared or tired or absent minded. The pleasures and disappointments of teaching at this level are correspondingly great" (Vale \& Feunteun, 1995). This explains that teaching young children is obviously challenging and a careful 
planning is required in order to engage them in language learning activities. A teacher has to be professionally competent enough to teach the young children and "the professionalism of teachers of young learners requires an underpinning of theoretical knowledge that can help counterpart prevalent misunderstanding of the job (teaching young children)" (Cameron, 2001). The two misunderstandings that are prevalent in teaching young children are as follow:

a) Teaching children is straightforward

b) Children only need to learn simple language

People often think that teaching young children is an easy job and anyone can teach at primary level as it is seen as an extension of mothering rather than as an intellectual enterprise. Teachers at primary level are then often given less training, lower status, and low pay than their colleagues in the same educational system who teach teenagers or adults. This is unfair both for the children and the teachers who teach them. According to Cameron, teachers of young children should be such that they need to understand the children, find out what they need and offer them the materials in a way that they take them with interest. "The teacher of children needs to be highly skilled to reach into children's world and lead them to develop their understandings towards more formal, more extensive and differently organized concepts" (Cameron, 2001, p. xii). Teachers of young children should be highly qualified and they should be able to understand the child psychology including the interest of young children so that the class can be effectively managed for enhanced language learning experience.
Another key misunderstanding about teaching young children is that children cannot learn complex language and thus should be taught the alphabets, simple words and very simple sentences with the numbers, colours and simple nursery rhymes and songs. The textbooks and learning materials are also designed accordingly thinking that children cannot learn big thing at the young age. This is completely a myth and children do have huge learning potential, and the foreign language classroom does them disservice if we do not exploit that potential (Cameron, 2001). Children do have knowledge of the world and they bring great topics to their class and they are highly interested to talk about them with their friends and their teachers.

\section{Teaching English to young children}

In order to teach English to the young children effectively, the teacher should have knowledge and skills of how the language should be presented at the very young age. "Experienced early childhood professionals encourage caregivers and teachers of young learners to provide developmentally appropriate instruction" (Linse, 2005). Teachers should establish a good rapport with the students and children must feel that their teacher is there to play with them. Personal relationships, in this context, are important to children, and the teacher must be ready to listen to stories about their families and accounts of daily happenings (Scott \& Ytreberg, 1990). Similarly, children love fun environment and they want to experiment things by themselves. They are inquisitive, imaginative and creative. "Young children do not come to the language classroom empty-handed. They bring with them an already established set of instincts, skills, and characteristics which will help them to learn 
another language" (Halliwell, 1992). English teachers of young children are expected to be smart enough to manage the energy and enthusiasm of the students in class. According to Scott and Ytreberg (1990), a language teacher of young children should make the following considerations:

a) Words are not enough: The language activities presented in class should be accompanied by the kinaesthetic movement including as many senses as possible. "You will need to have plenty of objects and pictures to work with and make full use of the schools and your surroundings" (Scott \& Ytreberg, 1990). Teacher can take the children outside the class and engage them in the physical activities along with the words and sentences that are targeted in the lesson.

b) Play with the language: Children love experiments. They want to try new things. When you present language, you can ask children to play with the language the way they like. "Let them talk nonsense, experiment with words and sounds: 'Let's go - pet's go.' 'Blue eyes - blue pies"' (Scott \& Ytreberg, 1990) etc. By doing this, they will practice the language.

c) Language as language: Let the children be aware of the language. Encourage them to read something and write whatever they can write or draw. The reading could be very simple with a lot of pictures and very few words. Even if they cannot read the words and sentences, they can read the pictures. Similarly, ask them to draw something and write down what they can. They might draw something and give the drawing names and make sense out of it.

d) Variety in the classroom: "Since the concentration and attention spans are short, variety is a must - variety of activity, variety of pace, variety of organization, variety of voice" (Scott \& Ytreberg, 1990). Teachers can do this by dividing the lesson into a series of activities incorporating the varieties of tasks in them. Children can be given the tasks of talking, playing, reading, writing, playing with words, drawing, etc. so that they keep their enthusiasm in learning the language by being involved in the varieties of tasks.

e) Routines: Prepare a tentative routine of the interesting activities for children so that they know what is coming next. Have a story time, fun time, game time and rhyme time in your routines. Children are motivated to complete the language tasks in anticipation of the interesting activities that follows the task(s).

f) Cooperation not competition: "Avoid rewards and prizes. Other forms of encouragement are much more effective. Make room for shared experiences - they are an invaluable source of language work and create an atmosphere of involvement and togetherness" (Scott \& Ytreberg, 1990).

g) Grammar: Children are good pickingup grammar rather than consciously learn the rules of language. Therefore, do not focus too much on grammar but inbuilt the structures into the language they are going to use in completing the task(s). Focusing too much on grammar 
may hinder their fluency and they might not be proactive to contribute to the discussion if you talk about the grammar in class.

h) Assessment: Paper pencil exams are not good for young children. Look at the progress of the students on a regular basis and use the continuous assessment model in order to monitor the progress of the students and offer remedial teaching in areas in which they need attention.

\section{Activities for teaching English to young children}

Teachers should present the language lesson in the form of activities. Children should be given range of tasks in class so that they do not feel pressure in learning language. Class can begin with a simple task to build their confidence and gradually the task(s) can be made more challenging. For example, you can start the class with an activity given in the box below:

\section{The seat on my right is empty}

\section{Procedure}

1. Begin by writing "The chair (or space/desk/whatever is used in your classroom) on my right is empty, and I'd like (student's name) to sit next to me." on the board.

2. Read the sentence yourself first and ask students to repeat after you several times so that they can say this correctly.

3. Next, have yourself and your students sit in a circle with an empty spot to the right of your spot in the circle.

4. Begin the game by saying the sentence on the board and using one of the student's names in the blank. The student you name should move to the space on your right, leaving an empty spot to the right of one of the students.

5. The student with the empty spot on their right should continue the game by saying the sentence and naming a new student to sit on his/her right.

6. After about two or three students have said the sentence, walk up to the board after each student has had a turn and start erasing words one or two at a time until there are no words left on the board.

7. Now, the student with the empty chair to his/her left should say the sentence.

8. As the game continues, the teacher should erase words from the sentence on the board. So, the third erasure would make the sentence look something like this: "The seat _ my right is empty, __ I'd like___ to sit next to __. The students will remember the words as they are erased. (see illustration below)

\section{Why it works}

This game helps students learn each other's names and builds a sense of community. It also helps students to learn a useful structure. The erasure helps students to gain confidence in their ability to learn English and helps. 


\section{Variation}

You ask students to bring their desks to a circle, and write the following mini-dialogue on the board:

A: Do you like your neighbours?

B: No, I don't.

A: Who would you like to sit next to you? and

Then, the two original neighbours and the other two have to swap places. Since there was no chair for you, you sit down, and one of the students will be in the middle. The game continues, and when the students are familiar with this swapping you say that if the answer is "yes, I do. I like my neighbours." everybody has to change places. Its lots of fun, an energy booster, and you may ask the student who stays in the middle a question. The students could prepare the questions before the game starts.

\section{Finger puppets}

Children love the puppets. Let's make finger puppets. It's easy. You can make them. What you need is a piece of paper and a staple. Use a piece of card about the size of a post card. Fold the card in half and staple the top and side. Draw or stick a cut-out of a picture on the card.

These can be used for short conversations. For example, one pupil takes a finger puppet and goes to the door of the classroom and knock. The conversation could go as follows:

Class: Come in!

Pupil: Hello!

Class: Hello! Who are you?

Pupil: Carlo.

Class: Sit down, please.

Pupil: Thanks.

Over a number of lessons the conversation gradually extends to other functions. Think of some examples such as requests, apology, etc.
These puppets can be used to represent the characters in the book as well. Similarly, they can also be used for a guessing game like each pupil chooses a finger puppet which s/he did not allow the other children to see. They then try to guess who he was by asking:

Are you Robin Hood?

Are you .......?

At a later stage, the children use finger puppets showing animals. Guessing then takes the form of asking questions like: Are you a monkey? Are you a tiger? etc.

\section{Telephone conversations}

Children enjoy pretending to talk to one another over the phone. They can use either a scripted conversation or improvise. For example,
A: Hello.
B: Hello. How are you?
A: OK. Come to my home. 
B: When?

A: at five.

The activity obviously becomes much more 'real' if toy telephone are available. Or you can ask the children to make paper telephone by drawing it on a card board paper or any scrap paper.

\section{Where are you?}

This is a controlled activity in giving directions, since children have quite a lot of difficulty with items such as: Turn (left), then turn (right). Or: Turn (left) and then (left) again.

This can be done with the help of a map with the names of the places such as cinema hall, school, shopping mall, etc.

You can begin the conversation like this. Go forward three squares. Stop! Turn right. Go forward six squares. Stop! Turn left. Go forward two squares. Stop! Where are you? The answer is: At the cinema or In front of the cinema.

\section{Find the difference}

Each pupil has a picture. The pictures are similar but there are some significant differences (e.g. mainly in the way the objects are arranged) as you can see from the card below. Two versions of this activity are:

a) The pupils place their cards side-by-side and see how many differences they can find.

b) The pupils do not show one another their cards but are asked to find out what the differences are (or to find out a specific number of differences) by talking to one another (i.e. by making statements, asking questions). For example.

A: Have you got a chair?

B: Yes. Where is your chair?

A: Near the door.

B: On the left?

A: No, on the right.

B: My chair's on the left of the door. It's on the mat.

A: I've got a mat too.

B: Is the chair on the mat?

A: No, there's a woman. (etc.)

If the activity can be played in the form of game, it is even better. Let's look at this game:

\section{Games}

Children love games. There are different games available for children. One of the simplest games that children love as a writing activity is given here in the box as a sample. You can create similar games for your students.

\section{Game: Crazy story}

Aim: Writing, reading aloud, listening, grammar (simple past tense, reported speech) Notes:

1. Prepare sheets of paper with six columns which bear the following titles at the top

- WHO?

(a man's name)

- WHOM?

(a woman's name) 
- WHERE?

- WHAT DID HE SAY?

- WHAT DID SHE SAY?

- WHAT DID THEY DO?

2. Divide the class into groups of 6 . Give each group one sheet of paper. Ask the first student to write under the first part and fold the paper so as to cover what he has written. Tell the student to pass the paper onto the next person. As each person writes, he should only look at his fold. When all students finish, one student from each group will be asked to read their story in the following format. You can write the format on the blackboard.

met in/at

- He said

- She said

And so they

\section{The perfect son.}
A: I have the perfect son.
B: Does he smoke?
A: No, he doesn't.
B: Does he drink whiskey?

A: No, he doesn't.

B: Does he ever come home late?

A: No, he doesn't.

B: I guess you really do have the perfect son. How old is he?

A: He will be six months old next Wednesday.

(Some of these activities were borrowed from Christine Stone's teacher training sessions)

You can find similar activities for young children in a book called Beginners (Grundy, 1995). The activities in this book are arranged according to the level of the learners and the language skills. Similarly, you can also find activities online and some of the web pages for young language learners are:

www.teachingenglish.org.uk www.learningenglish.org.uk www.americanenglish.state.gov

\section{Conclusion}

Teachers can enjoy teaching young learners if they know how to present the materials. The level of satisfaction is immensely great if you see the young kids using the language that you have taught in class. The most important thing is that you need to work on planning the lesson and you should be able to choose the appropriate materials for children. "Children bring to language learning their curiosity and eagerness to make sense of the world. They will tackle the most demanding tasks with enthusiasm and willingness" (Cameron, 2001). It is in the hand of the teacher who has to present the appropriate materials in classroom with a sequence of activities with reference to the age, level and interest of the learners. 


\section{About the author}

Mr. Gautam is Associate professor in English Education at Mahendra Ratna Campus, Tahachal, Kathmandu. He has authored many articles and books in ELT. He is former president of NELTA Central Committee.

\section{References}

Cameron, L. (2001). Teaching languages to young learners. Cambridge: Cambridge University Press.

Grundy, P. (1995). Beginners. Oxford: Oxford
University Press.

Halliwell, S. (1992). Teaching English in the primary classroom. New York: Longman.

Linse, C. T. (2005). Practical English language teaching: Young learners. New York: McGraw Hill.

Scott, W. A., \& Ytreberg, L. H. (1990). Teaching English to children. London: Longman.

Vale, D., \& Feunteun, A. (1995). Teaching children English: A training course for teachers of English to children. Cambridge: Cambridge University Press. 